\title{
Implementation of Halal Products on Moeslem Traveler's Awareness
}

\author{
${ }^{1}$ Asri Pebrianti, ${ }^{2}$ Muhammad Bilgary Utama, ${ }^{3}$ Terry Oktriviani \\ 1,2,3Universitas Muhammadiyah Mataram, Mataram, Indonesia \\ 1assripebrianti@gmail.com, ${ }^{2}$ muhammadbilgary@gmail.com, ${ }^{3}$ terryoktriviani@gmail.com
}

\begin{tabular}{|c|c|}
\hline Article Info & Abstract \\
\hline $\begin{array}{l}\text { Article History } \\
\text { Received: July 12, } 2018 \\
\text { Accepted: September 30, } \\
2018 \\
\text { Keywords } \\
\text { Halal; Haram; Awareness; } \\
\text { Health; Economy }\end{array}$ & $\begin{array}{l}\text { This research illustrates how the risk scheme of consuming non-halal } \\
\text { products for health is not onlyaboutdisadvantageto consumer health but } \\
\text { also their economics in the the future. Halal product consumption for } \\
\text { mankind has a good reason in terms of health and economic aspects that will } \\
\text { be generated. This writing aims to examine the behaviormoeslemtraveler in } \\
\text { consuming halal products, the behavior in the review is the awareness and } \\
\text { consistency in consuming the halal products. } \\
\text { The arguments are delivered with descriptive qualitative method. Data } \\
\text { collecting method used literature studies from Islamic rule literature, } \\
\text { previous research findings, and related text books. Studies of related } \\
\text { literature that became mainreference is the halal and haram restrictions in } \\
\text { Islam (the basic principle of consuming that has been established halal and } \\
\text { prohibited by Allah Azza wa Jalla (absolute). Some of products allowed to be } \\
\text { consumed and exploited until there is a special ban, as well as prohibited } \\
\text { because obviously the ugliness of the substance and prohibited because it } \\
\text { deals with the violation of God's right to Azza wa Jalla as it is obtained from } \\
\text { an incorrect path), the ethics of consumption in the Islamic perspective } \\
\text { (consuming as allowed and advocated by Al-Quran, Al-hadith and As- } \\
\text { Sunnah). Important findingsof previous studies that have proven the } \\
\text { negative effects of consuming non-halal products in health and financial } \\
\text { terms. The results of this study indicate that there are benefits to get when } \\
\text { consuming halal products, ranging from long-term health and financially in } \\
\text { the future.Moeslem traveler could be guided with the compact information } \\
\text { to obey halal-haram rules. }\end{array}$ \\
\hline $\begin{array}{l}\text { Support by: } \\
\text { dol Crossref }\end{array}$ & This is an open access article under the CC-BY-SA license \\
\hline
\end{tabular}

\section{INTRODUCTION}

The advancement of interstate mobility, it indirectly increases the interaction between citizens that does not rule out different beliefs. The differences in beliefs held by each citizen in a particular country must still be given their respective rights as a symbol of tolerance and peace between nations. For example, a Moeslim who is obliged to obey all that is ordered by his religion in accordance with the Islamic Shari'ah as per the rules of each religion that must be obeyed by its adherents. But in the Islamic Shari'a a Moeslim is obliged to consume halal products in all situations except in an emergency, migrating from one region to another does not make a Moeslim in an emergency because the emergency has its own specificity. So that the attention of Moeslims to their own obligations should be increased in order to save themselves.

Halal and Haram have become provisions in Islamic Shari'ah. Halal and haram provisions have also been established by Allah SubhanahuwaTa'ala in the Al-Quran which is supported by the Sunnah. So that all matters related to halal haram must refer back to the source of knowledge, namely the Al-Quran and the Sunnah. Halal and haram do not only cover foods or drinks, but processing in managing an item, where the source 
is obtained from and items made from certain materials. The thing that needs to be understood first is the determination of halal and haram is the right of Allah AzzawaJalla. Then what is lawful is everything that is validated by Allah AzzawaJalla and the haram is all that is forbidden by Allah AzzawaJalla in this understanding reason does not play a role at all. Then it is necessary to know in advance that the law of origin of food and drink is ibâhah (permissible) to be consumed or used in various ways until there is a special prohibition. Furthermore, the last is that there are two types of haram goods, first the goods which are forbidden by the substance and the khabits (obviously the ugliness), then the second is forbidden because it is related to the violation of the right of Allah AzzawaJalla because it is obtained through illegitimate means or violates the rights of fellow human beings like take force from someone else.

Some of theprohibitedhalal restrictions above, things that are halal or haram can be known. The things that have been forbidden by Allah SubhanahuwaTa'ala in terms of the substance contained in the Koran such as pigs, dogs, blood, carrion and khamr (intoxicating alcohol). These things have also been set by Allah AzzawaJalla in the Qur'an and various kinds of hadiths for their prohibition so that there is no doubt about their illegitimacy in the items that are already in the Quran. Then things that are forbidden because of the ugliness of the substance like cigarettes that do not provide benefits at all but provide mudharat (disadvantage) for consumers and the people around them. So that cigarettes are forbidden not only because the essence that gives bad effects but violance people around as well. Then that is forbidden because it is obtained from evil acts such as stealing or obtained from the way that Allah SubhanahuwaTa'ala prohibits such as halal animal slaughtered without reciting the name of Allah SubhanahuwaTa'ala.

In this world there are still a lot of people who still deny the truth of the Qur'an is no exception there are still some moeslims who wonder why these things are forbidden especially related to consumption. So that scientists also try to uncover the truth because there is no doubt in the Quran at all. Scientists reveal the Quran from various aspects of science, one of its sciences. Where the science reveals the things that God has forbidden from the health side that has an effect on consumers or reveals the effects of these haram goods to the surrounding environment. Not only limited to science, halal haram discussions are also related to economics where halal goods are also very influential on the world economy.

Discovery of the results of halal and haram research in terms of science and economics, it can invite and convince consumers to rethink if they will experiment with haram products in their lives. Because according to the literature obtained, it will not only bring financial losses but health losses and even life in the future for consumers. So that consumers will also be more careful or awareness of the consumer increases and most importantly consumer confidence will also increase and get blessings from Allah SubhanahuwaTa'ala. Because many people in this world even moeslims also have to be scientifically proven to be the reason for halal and the prohibition of a product to increase their awareness.

\section{METHOD}

This research includes the type of literature study research by looking for theoretical references that are relevant to the cases found. According to Nazir (1988) literature studies are data retrieval techniques by analyzing various books, literature, notes, and various reports relating to the problem to be solved. The type of data used by the authors in this study is secondary data, namely data obtained from previous literature studies, journals, and the internet. The theoretical references obtained by way 
of literature study research are used as the basic foundation and the main tool for research practice.

The object under study is about the awareness of Moeslimtravelers in implementing the use of halal products wherever they are.

The analytical method that used to develop a strategy for increasing of awareness on halal product uses by SWOT Analysis Method.

\section{RESULTS}

\section{Consumer Awareness}

What Did theMoeslem Travelers Get by Keeping an Awareness of Consuming Halal Products

As a Moeslem, we should follow things that are ordered and stay away from things that are forbidden by Allah SWT. Moeslemtravelers must increase their awareness of the importance of consuming halal products. By increase moeslimtraveler's awareness to consume halal products it means increasing the faith of a moeslim. Because by realizing this, it means that Moeslemtravelers have carried out one of their duties as a good moeslem. Eating halal products is a must for every moeslem wherever they are, all of this has been regulated in the law to consume halal foods and drinks that have been clearly explained in the Qur'an in the previous sub-chapter.

\section{Increased Awareness of Moeslim Travelers to Consume Halal Products Impact For Health}

The impact that will be obtained by moeslem travelers when they can maintain awareness to consume halal food or products, one of which is the maintenance of their health. Consuming hygienic halal foods can reduce the risk of infection with the disease, because in the process of making halal food has been regulated by the Al-Qur'an and Hadith. Research on water crystals that are beautifully formed when recited by a prayer and kept in a good environment. Then, according to the results of research conducted on the process of slaughtering animals, namely by cutting the jugular vein in animals, this will make the blood from animals dried out which helps to take all kinds of harmful substances from meat. Then further research was carried out at Secondary School Students in Nigeria about the effects of consuming alcoholic beverages, which have a negative impact on health. According to the WHO, alcohol consumption is currently the third largest risk factor in the world for diseases. When viewed from all previous studies, this shows that consuming halal foods and drinks can reduce the risk of getting the disease. For this reason, it is expected that moeslem travelers can maintain their awareness of the importance of consuming halal food and drinks wherever they are.

\section{Impact For Economy}

As explained above, consuming halal foods and drinks will reduce the risk of disease. By consuming healthy halal food, we will automatically reduce the cost of expenses for treatment of diseases. Surely this is very beneficial for moeslem travelers, with reduced medical costs when they are sick due to consuming food that is not halal and unhealthy, then they can save their money for other purposes.

\section{How Do Moslem Traveler Implement Halal Products to Increase Their Awareness}

Having an awareness of the importance of consuming halal products is indeed supposed to be applied in a moeslem traveler. But just having awareness is not enough, a moeslem traveler must be able to implement it in action. When they travel, they have to consume halal products. Probably in some places or countries halal products are still difficult to find, but there is no reason for moeslem travellers don't consume halal products because there is not an emergency. If moeslemtravelers go to a jungle or somewhere else and there are no goods to be eaten except haram goods such as boar, it 
might be breaking the rule that ordered to moeslem to consume halal foods because that is one of emergency. One solution, moeslimtravelers can make their own halal food, consume seafood or be a vegan or vegetarian. Thus, an awareness of the importance of consuming halal products will be perfect if Moeslem travelers can implement them wherever they are.

\section{CONCLUTIONS}

Allah SubhanahuwaTa'ala has written about all laws on Holy Quran. There is no doubt on it and moeslem must obey all His orders. One of laws on Quran is halal consumption. Moeslim should aware about this law wherever they are (exceptional on emergency).

All things on Quran always reasonable why we should or shouldn't to do. In this part, consume halal product is not without reason. From literatures that have been collected, we inform that halal products have many benefits for consumer's health or finance. Therefore, haram products have many disadvantages for consumer's health or finance. Concerning to the research result of literatures about halal haram products we could invite consumer to increase our awareness to halal products. Awareness of halal products is not only our duty of a moeslem but to protect ourselves from any disease or high spending on finance in further because more medical services needed.

\section{DAFTAR PUSTAKA}

[1] Ans, Muhammad. 2012. Healing Power of Water Myth or Reality. Available at: https://www.researchgate.net/publication/229083718 Healing Power of Water Myth or Reality. Accessed 7th May 2018.

[2] Eze, Ngozi M. PhD. Njoku, Helen Amaka PhD.Eseadi, Chiedu Med, et al. 2017. Alcohol consumption and awareness of its effects on health among secondary school students in Nigeria, Volume 96, Issue 48. Pg: 4-5. Available at: https://journals.lww.com/mdjournal/Fulltext/2017/12010/Alcohol consumption and awareness of its effects.76.aspx\#R1-76. Accessed 8th June 2018.

[3] LP POM MUI Bali. 2010. Pengertian Halal dan Haram MenurutAjaran Islam I. Bali. Online. Diakses pada $8^{\text {th }}$ August 2018 at: https://www.halalmuibali.or.id/pengertian-halal-dan-haram-menurutajaran-islam/. 